\title{
VARIATION IN CELL NUMBER IN \\ A POPULATION OF BEMBIX AMERICANA \\ (HYMENOPTERA: SPHECIDAE)*
}

\author{
By JoHn Alcock \\ Department of Zoology, Arizona State University, \\ Tempe, Arizona 8528I
}

This paper reports the results of observations made during the summers of 1971 and 1972 on a small group of Bembix americana Fabricius nesting in a vacant lot in Seattle, Washington. This population was judged to be intermediate to comata Parker and spinolae Lepeletier at the subspecific level (H. E. Evans, pers. comm.).

Probably no North American digger wasp has been more thoroughly studied than B. americana (Evans 1957, 1966; Evans and Matthews 1968). However there has only been one report of this species making nests with more than a single cell (Parker 1925). Evans (1966) notes the uniqueness of this account and the difficulty of accurately digging out nests in dense colonies. Nevertheless in the course of my work I discovered that some of the wasps in Seattle were making multi-celled nests. The evidence for this is presented here as well as data on the nest building behavior of marked females over a period of time.

\section{The Nesting Area}

Eleven species of sphecids and pompilids nested in a $13 \mathrm{~m}$ section of an old path running through a grassy area in a vacant lot in Seattle. The lot, which was largely covered with blackberry bushes (Rubus laciniatum), bordered Lake Washington and was within sight of the University of Washington. The nesting area was relatively open and somewhat less pebbly than other parts of the path. However, only a few places were truly sandy and most nests travelled in part or in whole through hard-packed gravelly earth with pebbles up to $5 \mathrm{~cm}$ in diameter present.

The 2 most abundant species in the aggregation were Philanthus crabroniformis Smith and $B$. americana; at the peak of the nesting season there may have been as many as 40 americana nests. In the summer of 197 I a group of nests were marked and closely watched for periods of I-3 hr almost every day between July 24 and August

*Manuscript received by the editor September 30,1972 
I4. The duration of activity at a burrow and the excavation of selected nests showed that some females constructed burrows with I, 2 , or 3 cells (Table I ).

Table 1. The number of cells per nest of Bembix americana in Seattle, Washington (1971).

\section{A. Excavated Nests}

$\begin{array}{ll}\text { Nests } & 1-3 \\ \text { Nests } & 4 \\ \text { Nests } & 5-10 \\ \text { Nests } & 11-13\end{array}$

B. Unexcavated Nests

Nests $14-15$

Nests 16-17

Nests 18

Nests $19-20$

Nests 21-22

\section{Duration of Observed} Activity at Nest

$9^{*}, 10^{*}, 14$ days

13

$8,8,9,9,9,10$

$2,4,6$
Number of Cells 3 3 ?

2

1

Probable Number of Cells 3 $2-3$ ? 2 $1-2$ ? 1

*Nest still active when excavated ; third cell contains fly with egg.

Nest $4-3$ cocoons located but details of the side burrows were unclear.

\section{RESULTS}

Table I summarizes the results of observation and excavation in 1971. Two points should be made here. (I) In many cases activity at a nest was not seen until the female had begun provisioning a cell. This means that the over-all length of activity at some nests is underestimated by 2 or 3 days. (2) Throughout the observation period weather conditions were such that females were able to work for a period of $2 \mathrm{wk}$ or more almost without interruption because of rain.

A variety of nests are illustrated in Fig. I. Judging from the 2 cases in which a third cell was found containing a fly and egg, females building three-celled nests first dug a more or less straight burrow leading to an initial cell. After completion of the provisioning of the first cell, a second one was added by digging a side burrow off at a right angle (more or less) from the main burrow. After this cell was dug and fully provisioned, a third burrow was constructed off the second cell burrow. This shaft circled back toward or under the main tunnel with the cell located well under the entrance to the nest. 

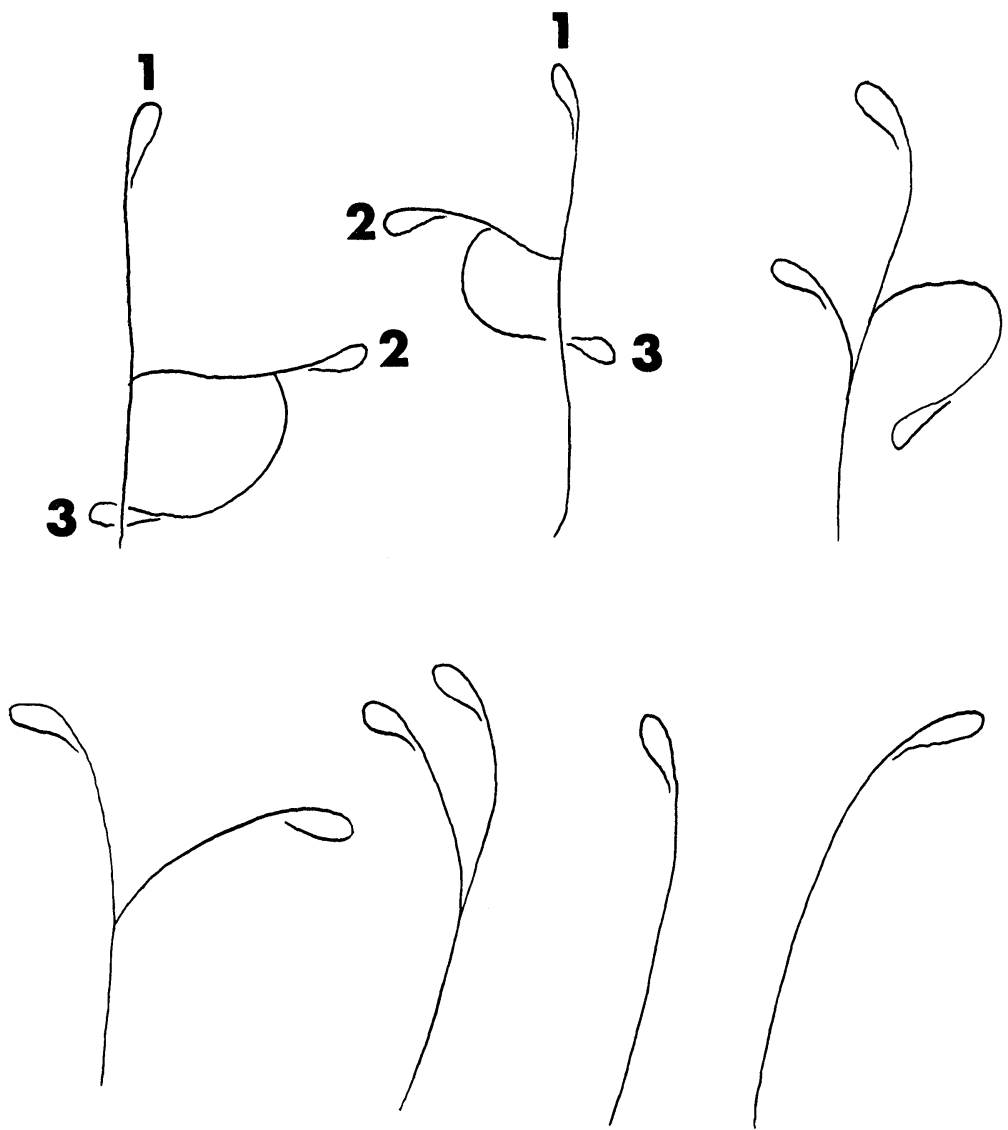

Figure 1. A view from above of a selected sample of nests. The cells are numbered in the order in which they were built (at the time of excavation cell 1 held a cocoon, cell 2 contained a larva, and cell 3 held a fly with an egg). 
The fact that wasps were building I, 2 or 3 celled nests raised the question, could an individual female construct more than one type of nest or was each wasp rigidly programmed to make either I or 2 or 3 celled nests?

In order to answer this question, a group of 16 wasps were marked on the thorax with a dot or dots of acrylic-vinyl paint after they had brought a prey to a nest. Each was given a distinctive color combination. Twelve of those marked completed one or more nests from the time of marking (July I4-2I, I972) to August 5 when I left the Seattle area.

Two wasps $(\mathrm{E}, \mathrm{H})$ that definitely made a single celled nest initially built a multi-celled nest the second time. For 3 others ( $I, K$, $L)$ this is probably the case. One female $(F)$ that made 2 single celled nests consecutively almost surely built a double celled nest the third time around. Only I wasp definitely built a second nest with fewer cells than the first one $(\mathrm{C})$.

The pattern of building single celled nests first and multicelled nests later is supported by indirect evidence from the I97 I data. The first year, observations of americana were not begun until later in the season (July 24 as opposed to July 14 in 1972). Less than I/4 of the I97I nests excavated were single-celled as opposed to $3 / 4$ of the initial nests in 1972 . I strongly suspect that most of the burrows excavated in 197 I were the second or third nests of the wasps, whereas in 1972 I made an effort to mark an individual as soon as it was discovered at a nest.

\section{Discussion}

This study shows that the females in at least one population of $B$. americana are capable of building either single or multi-celled nests. It suggests moreover that females tend first to build I celled nests and that subsequent nests are likely to have more than I cell.

Variation in cell number is not unknown in Bembix occurring in amoena, belfragei, cinerea, and niponica (Evans 1966, p. 277, $317,352)$. This is only the second report of such variation for the abundant, widespread and well-studied americana suggesting that multi-celled nests are rare for this species. It is noteworthy that Parker's description (I925) of the design of the 3 celled nests he studied in a population of $B$. a. comata matches mine to the extent that the final cell tended to be located under the main burrow near the entrance of the nest. 
Table 2. The nest building behavior of marked Bembix americana in Seattle, Washington (1972)

First Nest Second Nest Third Nest

\begin{tabular}{|c|c|c|c|c|c|c|}
\hline Wasp & Duration of Activity & Cells & : Activity & Cells & : Activity & Cells \\
\hline A & 14 days & $(3)$ & & & & \\
\hline B & 13 days & (3) & & & & \\
\hline $\mathrm{C}$ & 10 days & $2 \mathbf{E}$ & 5 & $1 E$ & & \\
\hline D & 8 days & $2 \mathrm{E}$ & $5 *$ & $1 *$ & & \\
\hline $\mathbf{E}$ & 7 days & $1 E$ & 9 & $2 \mathrm{E}$ & & \\
\hline $\mathbf{F}$ & 3 days & $1 \mathrm{E}$ & 4 & $1 \mathrm{E}$ & 8 & $(2)$ \\
\hline G & 2 days & $1 \mathrm{E}$ & 6 & $1 E$ & & \\
\hline $\mathrm{H}$ & 3 days & $1 \mathrm{E}$ & 12 & $2 \mathbf{E}$ & & \\
\hline I & 2 days & (1) & $11^{*}$ & $2 *$ & & \\
\hline $\mathrm{J}$ & 5 days & (1) & 2 & (1) & & \\
\hline K & 2 days & (1) & $10^{*}$ & $2 *$ & & \\
\hline $\mathbf{L}$ & 5 days & (1) & 9* & $2 *$ & & \\
\hline
\end{tabular}

Ecological Factors and Nest Design. The significance of variation in cell number for digger wasps has not been discussed in great detail. Presumably there are both advantages and disadvantages associated with the construction of either multi-celled or single celled nests. A nest with 3 cells may require the removal of less material in building than would 3 separate uni-celled nests. However the advantage of reduced energy expenditure in nest building may be tempered by (I) the disadvantage of prolonged activity at one nest entrance which may make the individual's larvae and prey more vulnerable to parasites, especially if the latter are capable of learning to exploit a specific source of prey and by (2) the disadvantage stemming from the possibility of a highly localized disaster which would eliminate all the offspring in a multi-celled nest before they could emerge (e.g. poor drainage at a particular site).

If these speculations are correct one would expect multi-celled nests in areas where soil conditions or other factors make nest construction particularly expensive in terms of time and energy costs. Evans notes (1966, p. 442) that nests with more than I cell are more characteristic of species digging in compact soil than those which build in sandy soils. Judging from Evans' account (1957) of typical nesting sites for americana the Seattle colony was located in an atypically hardpacked and pebbly area. These conditions may 
favor individuals that build multi-celled nests and thereby avoid having to dig through a stony compacted surface repeatedly. However the population studied by Parker nested in sand dunes where this argument cannot apply. Parker was deeply impressed by the powerful winds that regularly swept the area often blowing females away from their nest entrances. Perhaps with these conditions, selecting a new site and attempting to initiate digging would be both extremely time consuming and energetically demanding. This remains conjecture.

It should be noted moreover that this hypothesis is weakened by the fact that those Bembix that dig very long (up to I $\mathrm{m}$ ) burrows deep into sand dunes (e.g. occidentalis and pruinosa) do not construct multiple celled nests. Although these are large and powerful species, nonetheless the costs of nest building must be great. It is difficult to understand why one long burrow could not accommodate several cells.

Nevertheless, assuming that there is some imperfect relationship between the expense of nest building and multiple cells, one would expect intraspecific variation in nest design to occur in species which are most flexible in the selection of nesting areas. Most North American Bembix are relatively restricted to one soil type (Evans 1966, p. 352). However, amoena and americana are quite variable in nesting ecology while the requirements of the other species that make both single and multi-celled nests are uncertain.

As a final question, why should the females I watched have tended to build a single celled nest first and then a multi-celled one? Perhaps such a strategy insures that if a wasp is able to provision only 2 cells at least her offspring will be in 2 separate locations. But if she is able to provision more, it may then be to her advantage to reduce building costs by constructing side burrows and additional cells and to expend her time and energy in foraging and provisioning. Probably the middle of the nesting season coincides with the peak abundance of prey and the best weather conditions. Thus it may be especially important not to spend this time hunting for and digging a new nest, time that could be spent provisioning cells before the onset of the fall rains in Seattle (which often begin by mid-August). Thus the nest building behavior of a female americana in Seattle may reflect conflicting pressures to avoid placing all her eggs in one nest while at the same time making the most of the short time available to her to collect prey. 


\section{SUMMARY}

Females of a population of Bembix americana built complete nests with I, 2, or 3 cells at a site in Seattle, Washington. This is only the second report of variation in cell number for this well-studied species. Marked individuals generally built single-celled nests at the start of the season with subsequent nests likely to be multicelled. Speculations on the adaptive significance of multi-celled nests and the pattern of nest building observed in Seattle are presented.

\section{ACKNOWLEDGMENTS}

I am especially grateful to Dr. Howard E. Evans for his kindness in identifying the wasps, suggesting ideas for research, and reading an earlier draft of this paper. Virginia Anderson made a number of useful observations at the nest sites after I left the Seattle area and I thank her for her help. This work was done while the author was supported by NSF grants GB-28714X, GB-28714XI, and GB-35269.

\section{REFERENCES}

Evans, H. E.

1957. Studies on the comparative ethology of digger wasps of the genus Bembix. Cornell University Press, Ithaca, N. Y.

1966. The comparative ethology and evolution of the sand wasps. Harvard University Press, Cambridge.

Evans, H. E. ANd R. W. MatTHEWs

1968. North American Bembix, a revised key and suggested groupParker, J. B. ing. Ann. Entomol. Soc. Amer. 61: 1284-1299.

1925. Notes on the nesting habits of Bembix comata Parker. Proc. Entomol. Soc. Wash. 27 : 180-195. 

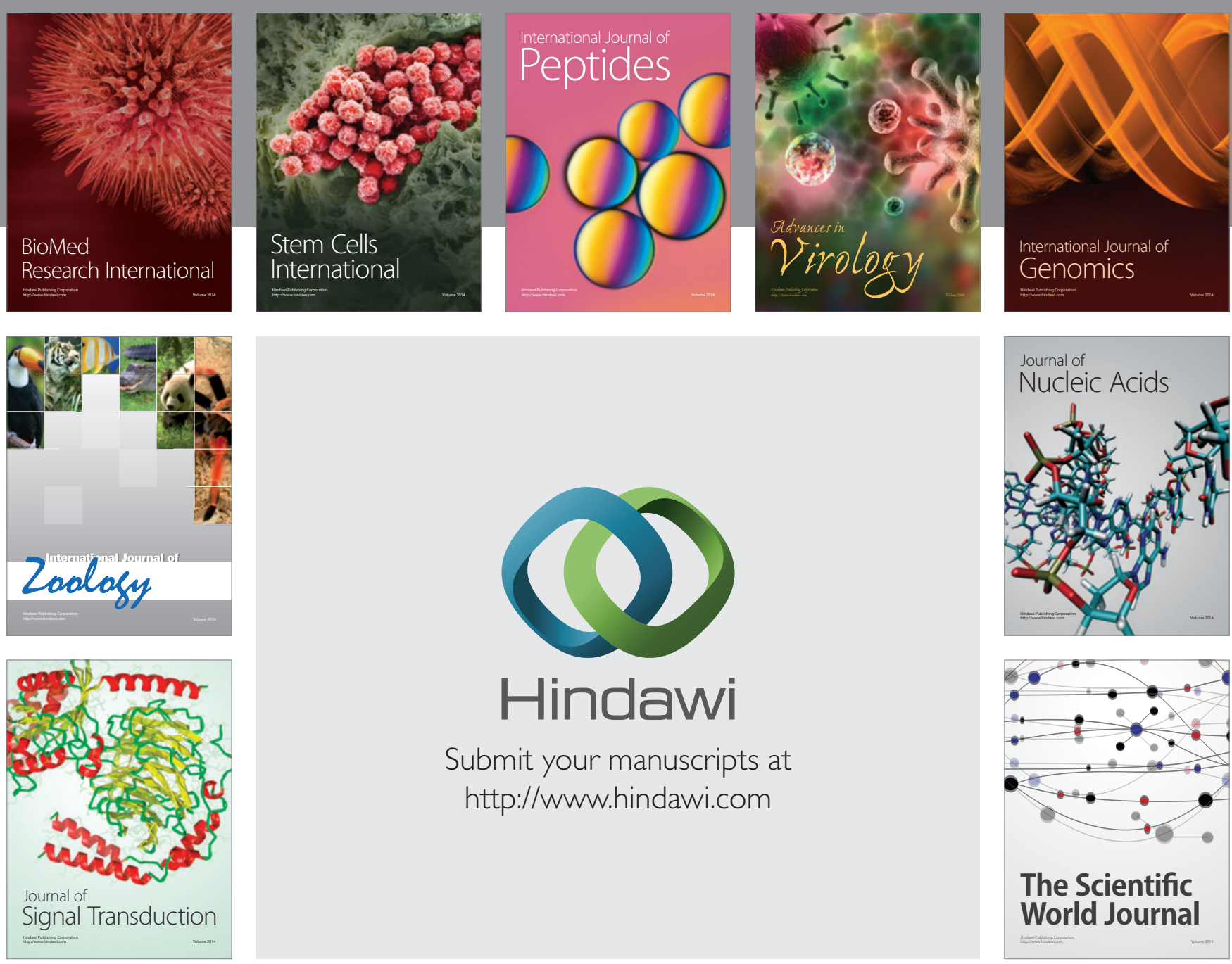

Submit your manuscripts at

http://www.hindawi.com
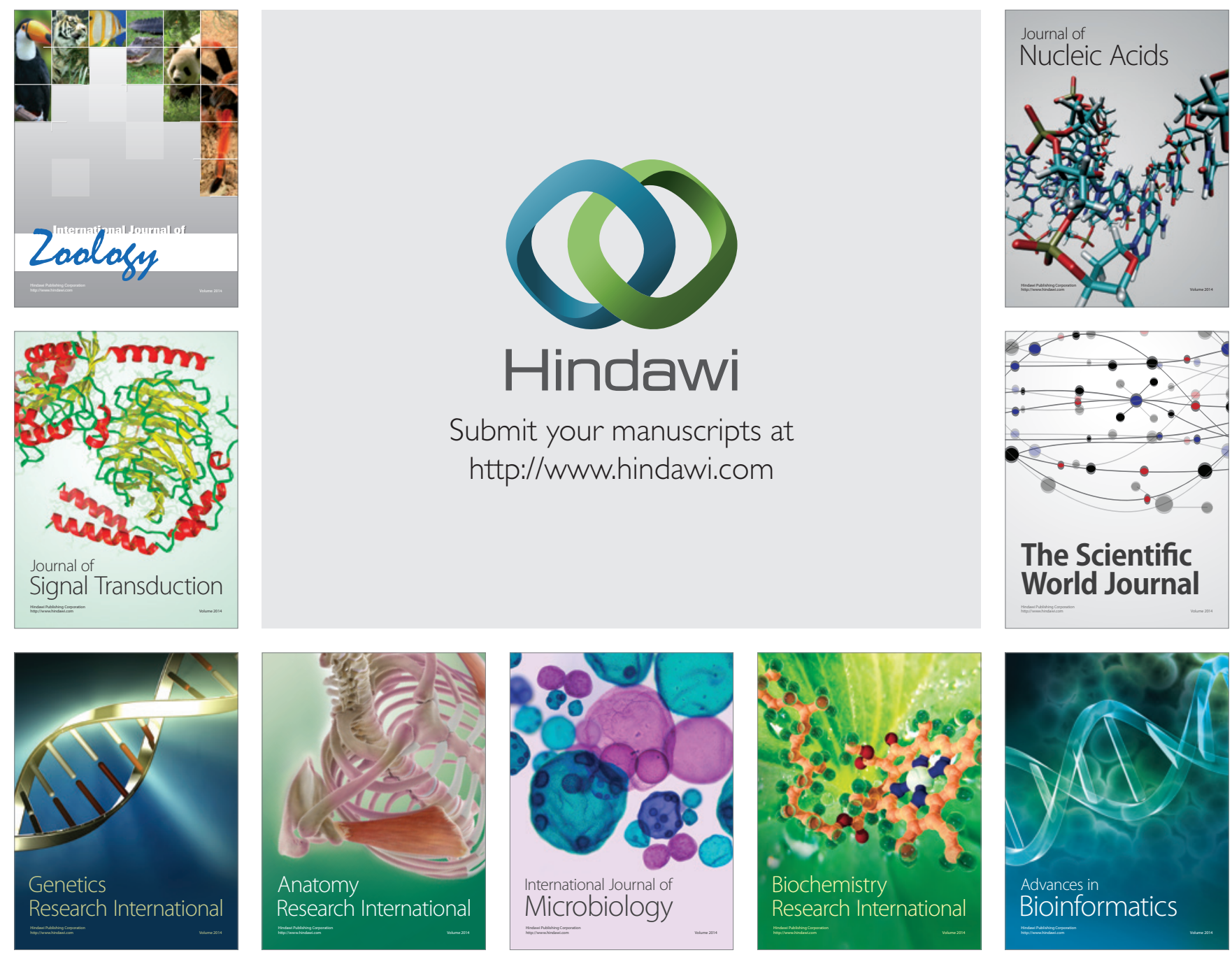

The Scientific World Journal
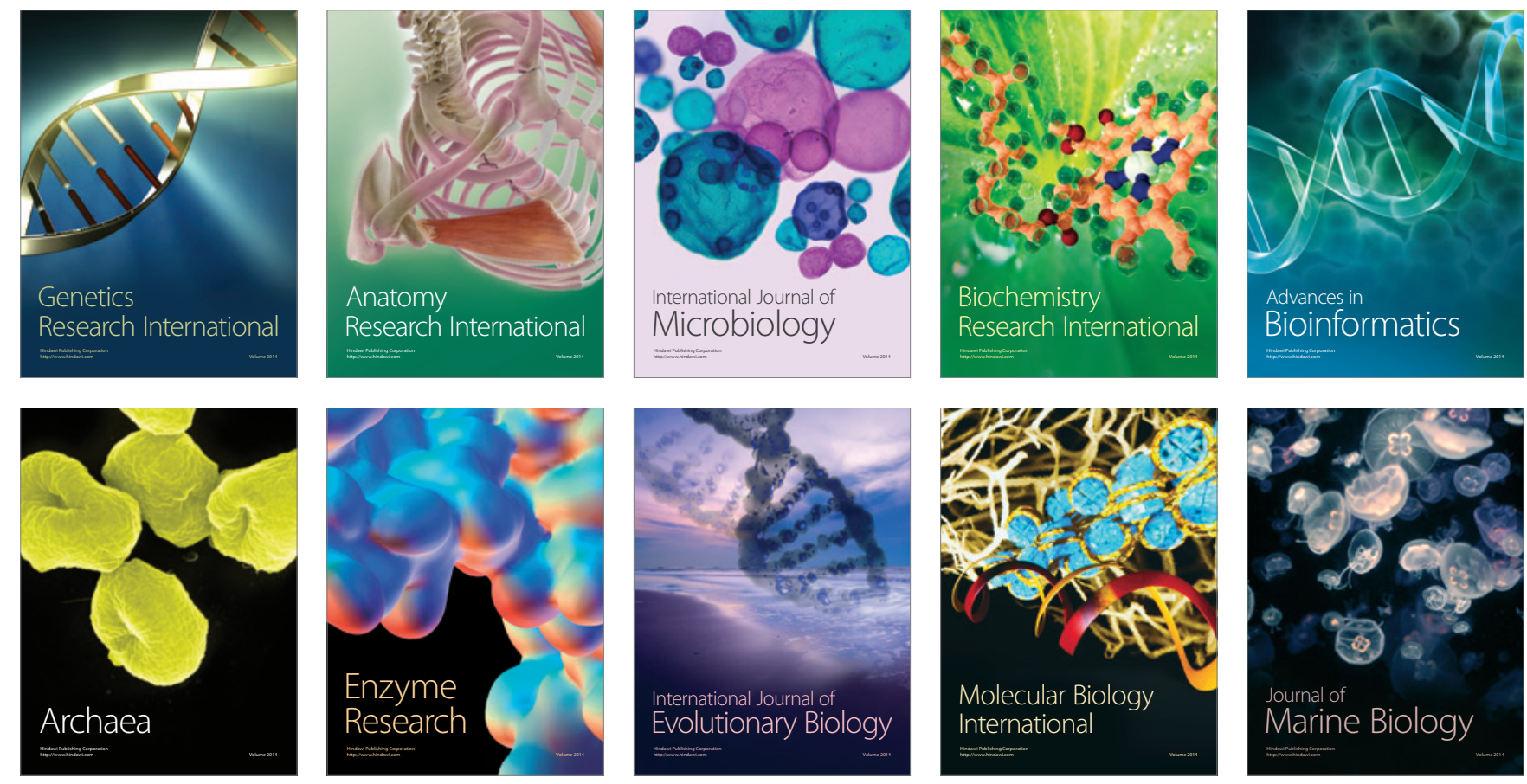